\title{
(6) OPEN ACCESS \\ Early academic achievement in children with isolated clefts: a population-based study in England
}

\author{
Kate Jane Fitzsimons, ${ }_{1}^{1}$ Lynn P Copley, ${ }^{1}$ Efrosini Setakis, ${ }^{2}$ Susan C Charman, ${ }^{1,3}$ \\ Scott A Deacon, ${ }^{4}$ Lorraine Dearden, ${ }^{2}$ Jan $\mathrm{H}$ van der Meulen ${ }^{1,3}$
}

${ }^{1}$ Clinical Effectiveness Unit, Royal College of Surgeons of England, London, UK

${ }^{2}$ UCL Institute of Education, University College London, London, UK

${ }^{3}$ Department of Health Services Research and Policy, London School of Hygiene \& Tropical Medicine, London, UK

${ }^{4}$ University Hospitals Bristol NHS Foundation Trust, London, UK

\section{Correspondence to}

Professor Jan H van der Meulen, Department of Health Services Research \& Policy, London School of Hygiene \& Tropical Medicine, 15 - 17 Tavistock Place, London WC1H 9SH, UK; Jan.vanderMeulen@Ishtm.ac.uk

Received 20 July 2017 Revised 28 August 2017

Accepted 13 September 2017

Published Online First

2 November 2017
Check for updates

To cite: Fitzsimons KJ, Copley LP, Setakis E, et al. Arch Dis Child

2018;103:356-362.

\section{ABSTRACT}

Objectives We used national data to study differences in academic achievement between 5-year-old children with an isolated oral cleft and the general population. We also assessed differences by cleft type.

Methods Children born in England with an oral cleft were identified in a national cleft registry. Their records were linked to databases of hospital admissions (to identify additional anomalies) and educational outcomes. Z-scores (signed number of SD actual score is above national average) were calculated to make outcome scores comparable across school years and across six assessed areas (personal development, communication and language, maths, knowledge of world, physical development andcreative development).

Results 2802 children without additional anomalies, 5 years old between 2006 and 2012, were included. Academic achievement was significantly below national average for all six assessed areas with z-scores ranging from $-0.24(95 \% \mathrm{Cl}-0.32$ to -0.16$)$ for knowledge of world to -0.31 ( -0.38 to -0.23$)$ for personal development. Differences were small with only a cleft lip but considerably larger with clefts involving the palate. $29.4 \%$ of children were documented as having special education needs (national rate $9.7 \%$ ), which varied according to cleft type from $13.2 \%$ with cleft lip to $47.6 \%$ with bilateral cleft lip and palate.

Conclusions Compared with national average, 5 -year-old children with an isolated oral cleft, especially those involving the palate, have significantly poorer academic achievement across all areas of learning. These outcomes reflect results of modern surgical techniques and multidisciplinary approach. Children with a cleft may benefit from extra academic support when starting school.

\section{INTRODUCTION}

Craniofacial abnormalities are among the most common of all birth defects. ${ }^{1}$ In England, about 900 children a year are born alive with a cleft lip (CL) and/or cleft palate (CP). ${ }^{2}$ A cleft can affect hearing, ${ }^{34}$ speech and language, ${ }^{56}$ dental health ${ }^{78}$ and psychosocial health. ${ }^{9}$ Children with a cleft may experience cognitive dysfunction, ${ }^{10-13}$ learning difficulties ${ }^{14} 15$ and lower levels of school achievement. ${ }^{15-19}$

Previous studies have explored the impact of the effect of oral clefts on school attainment in a range of populations varying in year of birth, age and type of educational outcome. Most of these studies were small and they reported inconsistent findings with respect to the overall impact of oral cleft and the specific impact of different cleft types. ${ }^{15-19}$ By far the

\section{What is already known?}

- Children with isolated oral clefts tend to have poorer educational outcomes than unaffected children.

- The reported size of the educational gap is variable, and reported differences in academic achievement between cleft types are inconsistent.

\section{What this study adds?}

- Compared to the general population in England 5 -year-olds with isolated clefts, especially those involving the palate, have significantly lower academic achievement scores and higher rates of special educational needs.

- Early educational interventions may benefit children with isolated oral clefts.

largest study to date presents the school attainment at the age of 16 years for 1992 individuals born with an oral cleft between 1973 and 1986 in Sweden. ${ }^{17}$ This study found that individuals with a cleft involving the palate were more likely not to receive their leaving certificate than the general school population, while there were no differences for individuals with a CL and no involvement of the palate.

The other studies, all carried out in the USA, present various school attainment outcomes in relatively small cohorts (with the largest study including 112 individuals with a cleft) ${ }^{151619}$ or in a larger cohort (including 588 individuals with cleft) created by including individuals born over a 20-year period (between 1983 and 2003). ${ }^{18}$ The smaller studies did not explore the impact of cleft type on outcomes, ${ }^{15} 1619$ whereas the larger study found very similar results, irrespective of whether or not the palate was involved. ${ }^{18}$

In England, the outcomes for children born with an oral cleft have gradually improved over the last two decades partly as the result of the further development of surgical techniques, the implementation of a multidisciplinary approach and the centralisation of cleft services. ${ }^{20} 21$ It is likely that similar improvements took place in many other countries.

To address the lack of information on school attainment in children whose cleft treatment most likely reflects current cleft care practice, we identified the records of children born with an oral cleft in England between 2001 and 2007 in a national 
clinical database and linked these to records of a national database of educational outcomes for all pupils in state schools in England. In this way, we could determine the differences in early school attainment between children with a cleft and the general population. The cohort that we created was also large enough to study whether there are differences in attainment between children with different cleft types.

\section{METHODS}

Study cohort, databases and record linkage

The study cohort was identified in the Cleft Registry and Audit Network (CRANE) database. CRANE collects information on all children born with an oral cleft in England, Wales and Northern Ireland (www.crane-database.org.uk). A total of 4587 children born in England who were 5 years old between 1 September 2006 and 31 August 2012 and whose parents had given consent for their records to be included in the CRANE database were eligible for linkage to the Hospital Episode Statistics (HES) database and the National Pupil Database (NPD) (see figure 1). Given that about 900 children are born with an oral cleft in England each year, ${ }^{22}$ about $85 \%$ could be considered for inclusion in this study.

Of the 4587 identified children with an oral cleft, 4255 (92.8\%) had a linked record in HES, which at the time of analyses contained records on all admissions to National Health Service (NHS) hospitals in England up to 31 March 2015. The NHS is a state-funded healthcare system which treats practically all children born with a cleft in England. Linkage to HES was used to exclude 984 of the 4255 children with a linked HES record (23.1\%) because they were identified as having additional anomalies or syndromes (ie, a non-isolated cleft) based on the presence of 33 specific International Classification of Diseases, 10th edition (ICD-10) diagnostic codes (see online Supplementary file 1) representing congenital malformations and chromosomal abnormalities in any of the diagnosis code fields of their HES records.

Of the remaining 3271 children with an isolated cleft, 2924 $(89.4 \%)$ had a linked record in the NPD. ${ }^{23}$ The NPD is a national database containing records on educational outcomes for all pupils of state schools in England from the 1995/1996 school year onwards. Between the 2006/2007 and 2011/2012 school years, the NPD contained the teacher-assessed the Early Years Foundation Stage Profile (EYFSP), collected for all children in the school year that they turned 5 years of age.

A further 122 children were excluded because we did not have information on cleft type $(n=40)$ or the EYFSP scores $(n=82)$. As a result, the linked CRANE-HES-NPD records of 2802 children were available for analysis.

\section{Ethics}

The study is exempt from NHS Health Research Authority ethics approval as it involves the analysis of an existing anonymised dataset that is collected for the purpose of service evaluation. ${ }^{24}$

\section{Patient characteristics}

Cleft type was categorised into four groups: CL), CP, unilateral $\mathrm{CL}$ and palate (UCLP) and bilateral CL and palate (BCLP).

Indicators of deprivation were obtained from NPD records. The Income Deprivation Affecting Children Index (IDACI) is an index of socioeconomic deprivation that is calculated for small areas (mean population about 1500) as the proportion of children under the age of 16 that live in low income

\section{Cleft Registry and Audit Network (CRANE)}

\section{Hospital Episode Statistics (HES)}

National Pupil Database (NPD)

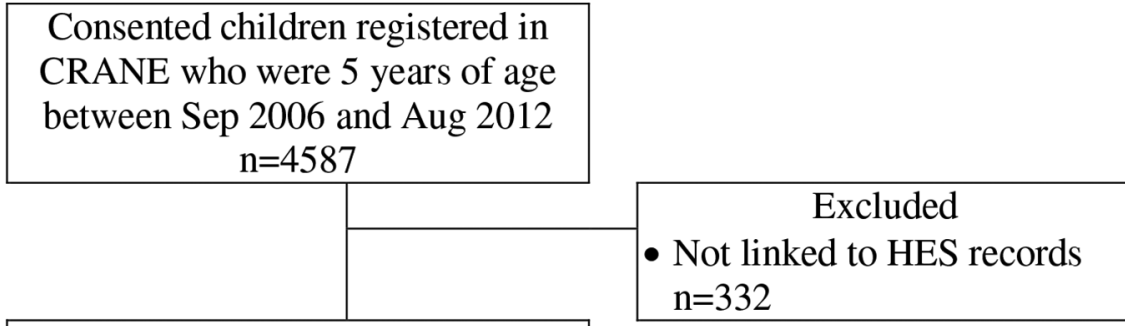

\begin{tabular}{|c|c|}
\hline $\begin{array}{l}\text { Linked to HES records } \\
n=4255\end{array}$ & \\
\hline & \multirow{2}{*}{\begin{tabular}{|l}
\multicolumn{1}{|c|}{ Excluded } \\
- Non-isolated oral clefts \\
$\mathrm{n}=984$
\end{tabular}} \\
\hline & \\
\hline $\begin{array}{l}\text { Children with isolated clefts } \\
n=3271\end{array}$ & \\
\hline & \multirow{2}{*}{$\begin{array}{l}\text { Excluded } \\
\text { - Not linked to NPD records } \\
\mathrm{n}=333\end{array}$} \\
\hline & \\
\hline $\begin{array}{c}\text { Linked to NPD records } \\
n=2924\end{array}$ & \\
\hline & \multirow{2}{*}{$\begin{array}{l}\text { - } \begin{array}{l}\multicolumn{1}{c}{\text { Excluded }} \\
\mathrm{n}=40 \\
\text { - } \\
\mathrm{n}=82\end{array} \\
\text { Missing NPD assessment }\end{array}$} \\
\hline & \\
\hline
\end{tabular}

Analysed

$\mathrm{n}=2802$

Figure 1 Identification of study cohort. 
households. National IDACI quintiles divide the areas into five roughly equal sized groups. ${ }^{25}$ Eligibility for free school meals is another indicator of the economic circumstances of the pupil's family. ${ }^{26}$ Data on ethnicity was taken from NPD records as was whether or not pupils had special educational needs (SEN).

\section{School attainment}

The EYFSP consists of 13 assessment scales with a maximum of nine points within each scale and a score of $\geq 6$ is the expected standard. These 13 scores are combined into mean scores representing six areas of learning (see table 1). We included children for whom we had EYFSP scores obtained between the school years of 2006/2007 and 2011/2012, because the EYFSP assessment changed significantly in $2012 / 2013$.

\section{Statistical analyses}

Between 2006/2007 and 2011/2012, national mean EYFSP results have improved each year. ${ }^{27}$ To account for this trend and for potential inconsistencies over time in scoring, z-scores were calculated for each assessment scale and area of learning within each assessment year using national population means and SD. Z-scores also allow a comparison of the effect that oral clefts have across the six areas of learning. A z-score represents the signed number of SD by which the child's actual score is above the national average. ${ }^{27}$ The SD within the national distributions for all six areas of learning fluctuated between 1.3 (physical development) and 1.8 (communication, language and literacy) which indicates that a difference of 1 between z-scores roughly corresponds to a difference of 1.5 points on the original 9-point scales. A negative z-score indicates that the score is below the national average. The primary outcomes were the mean $\mathrm{z}$-scores combining all six school years for each of the six areas of learning.

Multivariable linear regression was used to examine the effect of cleft type on the z-scores. The model included IDACI quintile and free school meal eligibility as measures of economic deprivation, ethnicity coded as 'white' or 'other' (including 'any other ethnic group', 'Asian', 'Black', 'Chinese' 'mixed' and 'unclassified') and sex. Likelihood ratio tests were used to determine the significance of each covariate in the regression model. All statistical calculations were performed in Stata 14 (Statacorp, College Station, Texas, USA).

\begin{tabular}{|c|c|}
\hline Area of learning & Assessment scale \\
\hline PSE & $\begin{array}{l}\text { Dispositions and attitudes } \\
\text { Social development } \\
\text { Emotional development }\end{array}$ \\
\hline CLL & $\begin{array}{l}\text { Language for communication and thinking } \\
\text { Linking sounds and letters } \\
\text { Reading } \\
\text { Writing }\end{array}$ \\
\hline MAT & $\begin{array}{l}\text { Numbers as labels for counting } \\
\text { Calculating } \\
\text { Shape, space and measures }\end{array}$ \\
\hline KUW & Knowledge and understanding of the world \\
\hline PD & Physical development \\
\hline$C D$ & Creative development \\
\hline
\end{tabular}

Areas of learning and assessment scales.

$C D$, creative development; CLL, communication, language and literacy; KUW, knowledge and understanding of the world; MAT, mathematical development; PD, physical development; PSE, personal, social and emotional development.
RESULTS

Table 2 presents the characteristics of the 2802 included children with an isolated oral cleft. About 1 in 3 had a CP, 1 in 4 a CL), another 1 in 4 a UCLP and 1 in 10 a BCLP. Table 2 also demonstrates that more boys $(58.7 \%)$ than girls $(41.3 \%)$ were included, which is to be expected in a cleft population, and that children in the most deprived national IDACI quintile were over-represented (with 24.5\%) and those in the least deprived quintile under-represented (with 14.8\%) given that per definition 20\% of children should be in each IDACI quintile. This discrepancy is to be expected as only state schools report data to NPD and the IDACI distribution observed for the included group of children with an isolated oral cleft closely matches the national distribution. ${ }^{28}$

\section{School attainment}

Children with an isolated oral cleft had z-scores that were significantly below the national average across all six assessed areas of learning (figure 2). The z-scores for the six areas of learning varied around -0.3 , which roughly corresponds to differences

Table 2 Characteristics of the included 2802 5-year-old children with an isolated oral cleft

\begin{tabular}{|c|c|c|}
\hline & $\mathrm{N}$ & $\%$ \\
\hline \multicolumn{3}{|l|}{ Type of cleft } \\
\hline $\mathrm{CL}$ & 767 & 27.4 \\
\hline $\mathrm{CP}$ & 973 & 34.7 \\
\hline UCLP & 773 & 27.6 \\
\hline BCLP & 289 & 10.3 \\
\hline \multicolumn{3}{|l|}{ Sex } \\
\hline Woman & 1157 & 41.3 \\
\hline Man & 1645 & 58.7 \\
\hline \multicolumn{3}{|l|}{ Ethnicity } \\
\hline White & 2252 & 80.4 \\
\hline Asian & 170 & 6.1 \\
\hline Black & 41 & 1.5 \\
\hline Other & 81 & 3.0 \\
\hline Unclassified & 249 & 8.9 \\
\hline Missing & 9 & 0.3 \\
\hline \multicolumn{3}{|l|}{ Major language } \\
\hline English & 2306 & 82.3 \\
\hline Other & 227 & 8.1 \\
\hline Missing & 269 & 9.6 \\
\hline \multicolumn{3}{|l|}{ IDACl quintile } \\
\hline 1 (most deprived) & 685 & 24.5 \\
\hline 2 & 613 & 21.9 \\
\hline 3 & 543 & 19.4 \\
\hline 4 & 500 & 17.8 \\
\hline 5 (least deprived) & 414 & 14.8 \\
\hline Missing & 47 & 1.7 \\
\hline \multicolumn{3}{|c|}{ Free school meal eligibility } \\
\hline No & 2227 & 79.5 \\
\hline Yes & 542 & 19.3 \\
\hline Missing & 33 & 1.2 \\
\hline \multicolumn{3}{|l|}{ SEN identified } \\
\hline No & 1954 & 69.7 \\
\hline Yes & 815 & 29.1 \\
\hline Missing & 33 & 1.2 \\
\hline
\end{tabular}

$B C L$, bilateral cleft lip and palate; $C L$, cleft lip; $C P$, cleft palate; IDACI, Income Deprivation Affecting Children Index; SEN, special educational needs; UCLP, unilateral cleft lip and palate. 
of between -0.4 and -0.5 points below the national average on the original 9-point scales.

The z-scores for the six areas of learning varied according to cleft impact ( $\mathrm{p}$ always $<0.001$ ). Figure 3 demonstrates that children with CL had better z-scores (varying around -0.1 for all six areas) than children with (figure 3) a cleft affecting the palate (varying between -0.3 and -0.5 ). Children with CL had $\mathrm{z}$-scores that were not statistically significant $(\mathrm{p}>0.05)$ from the general population mean in the knowledge and understanding of the world area.

The results of the linear regression analyses confirm that the effect of cleft types that involves the palate was considerably larger than that of clefts that only involves the lip (table 3). Adjusted for socioeconomic deprivation, free school meals, ethnicity and sex, differences in $\mathrm{z}$-scores between children with a CL and those with a cleft involving the palate vary between 0.2 and 0.4 across the six areas of learning.

The effects observed for the other factors included in the linear regression models can be used to appreciate the size of the effect of an isolated oral cleft on school attainment. For example, differences in z-scores between the least and most socioeconomically deprived IDACI quintile vary between 0.5 and 0.7 across the six areas. These differences are about twice as large as the overall effect of a cleft involving the palate. Differences in z-scores between children who are and who are not entitled to free school meals are of similar size as the effect of a cleft involving the palate. Table 3 also shows that scores for boys are typically lower than for girls across all areas of learning with the greatest differences being seen in physical development and creative development.

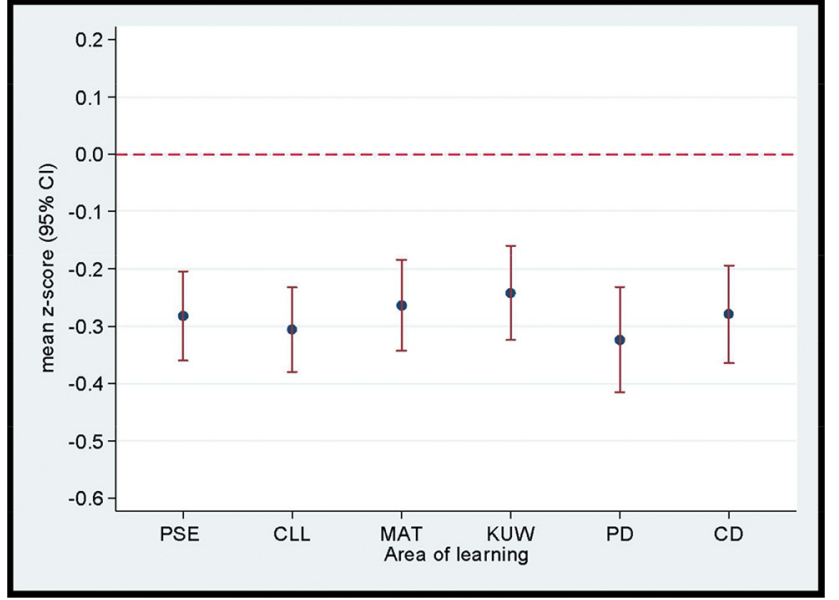

Figure 2 Mean z-scores and 95\% Cls for each area of learning at 5 years of age in children with an isolated cleft compared with the general population mean. See the text for further explanation. CD, creative development; $C L L$, communication, language and literacy; KUW, knowledge and understanding of the world; MAT, mathematical development; PD, physical development; PSE, personal, social and emotional development.

\section{Special educational needs}

The SEN status was documented for 2769 of the 2802 included children (98.8\%). Of these 2769 children, 815 (29.4\%) were identified as having SEN at 5 years of age. The proportion of

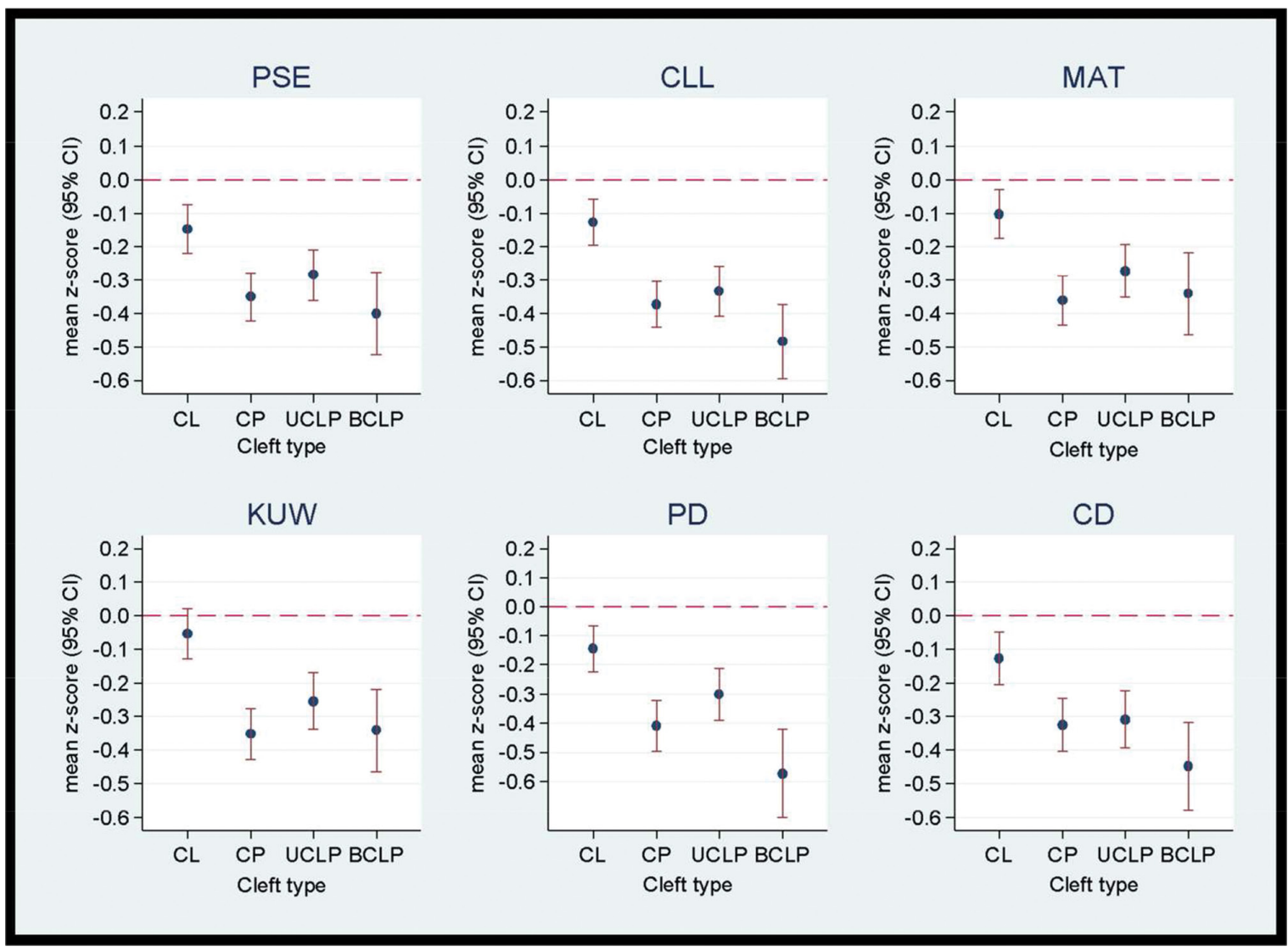

Figure 3 Mean z-scores and $95 \%$ Cls according to each area of learning at 5 years of age according to cleft type and compared with the general population mean. See the text for further explanation. BCLP, bilateral cleft lip and palate; CD, creative development; CL, cleft lip; CLL, communication, language and literacy; $C P$, cleft palate; KUW, knowledge and understanding of the world; MAT, mathematical development; PD, physical development; PSE, personal, social and emotional development; UCLP, unilateral cleft lip and palate. 
Table 3 Results of multivariable linear regression analyses of effect of cleft type on the z-scores for the six assessed areas of learning of the Early Years Foundation Stage Profile (difference compared with $\mathrm{CL}$ with $95 \% \mathrm{Cl}$ )

\begin{tabular}{|c|c|c|c|c|c|c|}
\hline Characteristic & $\begin{array}{l}\text { Personal, social } \\
\text { and emotional } \\
\text { development }\end{array}$ & $\begin{array}{l}\text { Communication, } \\
\text { language and literacy }\end{array}$ & $\begin{array}{l}\text { Mathematical } \\
\text { development }\end{array}$ & $\begin{array}{l}\text { Knowledge and } \\
\text { understanding of the } \\
\text { world }\end{array}$ & Physical development & Creative development \\
\hline \multicolumn{7}{|l|}{ Cleft type } \\
\hline $\mathrm{CL}$ & $\mathrm{rc}$ & $\mathrm{rc}$ & $\mathrm{rc}$ & rc & rc & $\mathrm{rc}$ \\
\hline $\mathrm{CP}$ & $-0.25(-0.35$ to 0.15$)$ & $-0.28(-0.38$ to 0.19$)$ & $-0.27(-0.37$ to 0.17$)$ & $-0.31(-0.41$ to 0.20$)$ & $-0.32(-0.44$ to 0.20$)$ & $-0.28(-0.39$ to 0.18$)$ \\
\hline UCLP & $-0.11(-0.22$ to 0.01$)$ & $-0.19(-0.28$ to 0.09$)$ & $0.15(-0.26$ to 0.05$)$ & $-0.18(-0.29$ to 0.07$)$ & $-0.14(-0.26$ to 0.01$)$ & $-0.15(-0.26$ to 0.03$)$ \\
\hline BCLP & $-0.19(-0.33$ to 0.05$)$ & $-0.30(-0.43$ to 0.17$)$ & $-0.19(-0.33$ to 0.04$)$ & $-0.25(-0.40$ to 0.10$)$ & $-0.37(-0.54$ to 0.21$)$ & $-0.25(-0.40$ to 0.10$)$ \\
\hline \multicolumn{7}{|l|}{ IDACI } \\
\hline 1 (most deprived) & $\mathrm{rc}$ & $\mathrm{rc}$ & $\mathrm{rc}$ & rc & rc & $\mathrm{rc}$ \\
\hline 2 & $0.09(-0.02$ to 0.21$)$ & 0.11 (0.00 to 0.22 ) & 0.18 (0.07 to 0.30$)$ & 0.23 (0.11 to 0.35$)$ & $0.13(-0.01$ to 0.27$)$ & 0.16 (0.03 to 0.28$)$ \\
\hline 3 & $0.25(0.13$ to 0.37$)$ & 0.32 (0.21 to 0.44$)$ & 0.40 (0.28 to 0.53$)$ & 0.45 (0.32 to 0.58$)$ & $0.30(0.15$ to 0.44$)$ & 0.37 (0.24 to 0.50$)$ \\
\hline 4 & 0.41 (0.29 to 0.54 ) & $0.48(0.36$ to 0.59$)$ & 0.55 (0.42 to 0.68$)$ & 0.54 (0.40 to 0.67$)$ & 0.43 (0.28 to 0.58$)$ & 0.50 (0.36 to 0.63 ) \\
\hline 5 (least deprived) & 0.51 (0.37 to 0.64$)$ & 0.58 (0.46 to 0.71$)$ & 0.71 (0.57 to 0.84 ) & 0.69 (0.55 to 0.83$)$ & 0.53 (0.37 to 0.69 ) & 0.59 (0.45 to 0.74$)$ \\
\hline \multicolumn{7}{|l|}{ Free school meals } \\
\hline No & $\mathrm{rc}$ & $\mathrm{rc}$ & $\mathrm{rc}$ & rc & re & $\mathrm{rc}$ \\
\hline Yes & $-0.38(-0.48$ to 0.27$)$ & $-0.47(-0.57$ to 0.38$)$ & $-0.41(-0.52$ to 0.31$)$ & $-0.36(-0.47$ to 0.25$)$ & $-0.34(-0.46$ to 0.21$)$ & $-0.35(-0.46$ to 0.24$)$ \\
\hline \multicolumn{7}{|l|}{ Ethnicity } \\
\hline White & $\mathrm{rc}$ & $\mathrm{rc}$ & $\mathrm{rc}$ & rc & rc & $\mathrm{rc}$ \\
\hline Other & $-0.07(-0.17$ to 0.03$)$ & $-0.08(-0.18$ to 0.01$)$ & $-0.14(-0.24$ to 0.03$)$ & $-0.14(-0.25$ to 0.03$)$ & $-0.05(-0.17$ to 0.07$)$ & $-0.08(-0.19$ to .03$)$ \\
\hline \multicolumn{7}{|l|}{ Sex } \\
\hline Girls & rc & $\mathrm{rc}$ & $\mathrm{rc}$ & rc & rc & $\mathrm{rc}$ \\
\hline Boys & $-0.36(-0.44$ to -0.28$)$ & $-0.33(-0.41$ to -0.26$)$ & $-0.18(-0.26$ to 0.10$)$ & $-0.15(-0.24$ to 0.07$)$ & $-0.42(-0.52$ to 0.32$)$ & $-0.58(-0.66$ to 0.49$)$ \\
\hline R-squared & 0.10 & 0.14 & 0.12 & 0.10 & 0.08 & 0.12 \\
\hline
\end{tabular}

BCLP, bilateral cleft lip and palate; CL, cleft lip; CP, cleft palate; IDACl, Income Deprivation Affecting Children Index; rc, reference category; UCLP, unilateral cleft lip and palate.

children with SEN varied according to cleft type. Children with CL were least likely to have SEN (13.2\%), whereas SEN were documented in $33.1 \%$ of children with CP, in $34.1 \%$ with UCLP and in $47.6 \%$ with BCLP. Among children with SEN identified, $565(66.6 \%)$ had the type of SEN specified and $105(18.6 \%)$ of these had more than one type of SEN recorded. Speech, language and communication needs was the most commonly documented type of SEN, which was specified for almost three-quarters of those children for whom a SEN type was documented (table 4).

\section{DISCUSSION}

This English population-based study demonstrates that academic achievement of 5-year-old children born between 2001 and 2007 with an oral cleft but without additional anomalies or syndromes is below the national average for all six assessed areas of learning. The differences were relatively small for children with a CL but substantially larger for children who have a cleft that involved the palate. The effect of an isolated oral cleft is similar across all assessed areas and therefore not limited to communication, language and literacy.

Table 4 The frequency (number and percentage) of specific types of SEN in the 565 children with a documented special educational need*

\begin{tabular}{lcc}
\hline SEN type & N & $\%$ \\
\hline Behaviour, emotional and social difficulties & 52 & 9.2 \\
Hearing impairment & 43 & 7.6 \\
Learning difficulties & 77 & 13.6 \\
Speech, language and communication needs & 416 & 73.6 \\
Other & 81 & 14.3 \\
\hline
\end{tabular}

*Some children had more than one type of SEN specified, so the percentages total $>100$.

SEN, special educational needs.
Another important finding from our study is that $29.7 \%$ of children with an isolated oral cleft were identified as having SEN which is about three times higher than the national rate of 9.7\% among 5 years old in England during the same time frame. ${ }^{27}$ Again, differences were relatively small for children with a CL but larger for children with a cleft involving the palate.

Only one other study has examined academic attainment among a cleft population at a national level. ${ }^{17}$ A Swedish study of school outcomes of 1992 16-year-old children found that compared with the general population individuals with a cleft had lower grade point averages and higher odds of not receiving a school leaving certificate. However, this study included individuals born between 1973 and 1986 and their academic outcomes may not reflect those that can be achieved by current cleft care. ${ }^{2021}$

The largest study carried out in Iowa included 588 children between 1983 and 2003 with an isolated cleft. Their academic outcomes between 7 and 17 years were significantly lower in all subject areas compared with classmates. ${ }^{18}$ This study did not find statistically significant differences between cleft types. A related study, including 256 children of this Iowa cohort, found no significant differences in academic achievement scores compared with 387 unaffected siblings. ${ }^{29}$ The researchers suggest that exposures shared by the affected and the unaffected siblings, such as a 'genetic vulnerability to learning problems' and the family environment, may explain the lack of differences.

A much smaller study carried out in the USA found no significant differences in early language and reading skills between 57 children with an oral cleft and 77 controls. ${ }^{30}$ Apart from lack of statistical power, the authors suggest as a possible explanation for the lack of differences that up to half of all children with a cleft had received speech interventions. In England, a large proportion of children with a cleft involving the palate receive speech and language therapy prior to starting school. Our findings show 
that, in spite of this, a significant attainment gap exists between those with a cleft and the general population.

A major strength of our study is the use of a national population-based sample, including 2802 children who represent about two thirds of the total eligible population. The registration of children with a cleft in the CRANE database strongly depends on the cleft centre where the children received their cleft care rather than on particular patient characteristics. ${ }^{22}$ Also, parental consent rate for registration is very high (around 98\%). All this indicates that our results are nationally representative.

Another strength of our study is that it consisted solely of children in the first year of the English state school system. Further follow-up will allow us to explore whether attainment gaps narrow or broaden as children progress through the school system. Nearly all other studies reporting educational outcomes in children with an oral cleft are based on samples of children including a wide age range.

A limitation of our study is that the identification of children with additional anomalies or syndromes was based on the presence of certain ICD-10 codes, including those representing DiGeorge syndrome and Pierre-Robin syndrome in the children's hospital records. It is possible that some children included in our analyses had additional conditions that were not in our prespecified list of diagnoses, which for example may include prenatal exposure to valproate. However, we feel that only very few children with additional conditions will be included because we checked the records of all hospital episodes in their first 5 years of life.

A further limiting factor is that academic attainment was based on teacher assessment.31 Future work will examine the impact of a cleft on externally assessed exams at later years, which will overcome the potential limitation of teacher assessment bias.

\section{Conclusions}

Children with isolated oral clefts, especially those that involve the palate, have significantly poorer academic achievement results across all assessed areas of learning and they are more frequently documented as having SEN than the general school population.

These academic differences already exist at the start of the school system when the children are just 5 years old, which demonstrates that early educational interventions may be of benefit. All children were born after August 2001 and their cleft-related outcomes largely reflect those that can be achieved with the use of modern surgical techniques and a well-coordinated multidisciplinary team approach.

\section{Acknowledgements HES data were made available by the NHS Health and Social Care Information Centre (C2012, reused with permission of the Health and Social} Care Information Centre. All rights reserved).

Contributors KJF: conceptualised and designed the study, carried out the analyses and interpretation of data, drafted the initial manuscript, revised the manuscript, approved the final manuscript as submitted and agreed to be accountable for all aspects of the work. JHvdM and SAD: conceptualised and designed the study, reviewed and edited the manuscript, approved the final manuscript as submitted and agreed to be accountable for all aspects of the work. LPC: conceptualised and designed the study, coordinated and managed the data collection from the three datasets, processed the Hospital Episode Statistics data, commented on the initial manuscript, approved the final manuscript as submitted and agreed to be accountable for all aspects of the work. LD: critically reviewed the manuscript, approved the final manuscript as submitted and agreed to be accountable for all aspects of the work. ES: carried out the dataset linkage rate analyses, commented on the initial manuscript, approved the final manuscript as submitted and agreed to be accountable for all aspects of the work. SCC: assisted in the statistical analyses of the data, commented on the initial manuscript, approved the final manuscript as submitted and agreed to be accountable for all aspects of the work.

Funding This work was funded by the National Specialised Commissioning Group for England and the Wales Specialised Health Services Committee and was carried out by the team of the CRANE database (the National Cleft Database of England, Wales, and Northern Ireland), which is overseen by the UK NHS Cleft Development Group. The funders did not have a role in in study design; in the collection, analysis, and interpretation of data; in the writing of the report; and in the decision to submit the paper for publication. JvdM is partly supported by the National Institute for Health Research Collaboration for Leadership in Applied Health Research and Care North Thames at Bart's Health NHS Trust.

Provenance and peer review Not commissioned; externally peer reviewed.

Data sharing statement The study cohort was identified in the Cleft Registry and Audit Network (CRANE) database. CRANE records were linked to Hospital Episode Statistics and National Pupil Database. Data can be shared if approval has been obtained from the owners of these three databases.

Open Access This is an Open Access article distributed in accordance with the Creative Commons Attribution Non Commercial (CC BY-NC 4.0) license, which permits others to distribute, remix, adapt, build upon this work non-commercially, and license their derivative works on different terms, provided the original work is properly cited and the use is non-commercial. See: http://creativecommons.org/licenses/by-nc/4.0/

(c) Article author(s) (or their employer(s) unless otherwise stated in the text of the article) 2018. All rights reserved. No commercial use is permitted unless otherwise expressly granted.

\section{REFERENCES}

1 Stanier P, Moore GE. Genetics of cleft lip and palate: syndromic genes contribute to the incidence of non-syndromic clefts. Hum Mol Genet 2004;13 Spec No 1:73R-81.

2 Fitzsimons KJ, Copley LP, Deacon SA, et al. Hospital care of children with a cleft in England. Arch Dis Child 2013;98:970-4.

3 Atkinson M. Surgical management of otitis media with effusion in children-NICE guideline: what paediatricians need to know. Arch Dis Child Educ Pract Ed 2009;94:115-7.

4 Fitzsimons KJ, Copley LP, van der Meulen JH, et al. Grommet Surgery in Children With Orofacial Clefts in England. Cleft Palate Craniofac J 2017;54:80-9.

5 Mildinhall S. Speech and language in the patient with cleft palate. Front Oral Biol 2012;16:137-46.

6 Ruiter JS, Korsten-Meijer AG, Goorhuis-Brouwer SM. Communicative abilities in toddlers and in early school age children with cleft palate. Int J Pediatr Otorhinolaryngol 2009;73:693-8.

7 Britton KF, Welbury RR. Dental caries prevalence in children with cleft lip/palate aged between 6 months and 6 years in the West of Scotland. Eur Arch Paediatr Dent 2010;11:236-41.

8 Fitzsimons KJ, Copley LP, Smallridge JA, et al. Hospital admissions for dental treatment among children with cleft lip and/or palate born between 1997 and 2003: an analysis of Hospital Episode Statistics in England. Int J Paediatr Dent 2014;24:200-8.

9 Rumsey N, Stock NM. Living with a Cleft: Psychological Challenges, Support and Intervention. Berkowitz S, ed. Cleft Lip and Palate: Diagnosis and Management. . Berlin, Heidelberg: Springer Berlin Heidelberg, 2013:907. 15

10 Hentges F, Hill J, Bishop DV, et al. The effect of cleft lip on cognitive development in school-aged children: a paradigm for examining sensitive period effects. J Child Psychol Psychiatry 2011;52:704-12.

11 Conrad AL, Richman L, Nopoulos P, et al. Neuropsychological functioning in children with non-syndromic cleft of the lip and/or palate. Child Neuropsychol 2009;15:471-84.

12 Richman LC, McCoy TE, Conrad AL, et al. Neuropsychological, behavioral, and academic sequelae of cleft: early developmental, school age, and adolescent/young adult outcomes. Cleft Palate Craniofac J 2012;49:387-96.

13 Jocelyn LJ, Penko MA, Rode HL. Cognition, communication, and hearing in young children with cleft lip and palate and in control children: a longitudinal study. Pediatrics 1996;97:529-34.

14 Yazdy MM, Autry AR, Honein MA, et al. Use of special education services by children with orofacial clefts. Birth Defects Res A Clin Mol Teratol 2008;82:147-54.

15 Broder HL, Richman LC, Matheson PB. Learning disability, school achievement, and grade retention among children with cleft: a two-center study. Cleft Palate Craniofac J 1998;35:127-31.

16 Knight J, Cassell CH, Meyer RE, et al. Academic outcomes of children with isolated orofacial clefts compared with children without a major birth defect. Cleft Palate Craniofac J 2015;52:259-68.

17 Persson M, Becker M, Svensson H. Academic achievement in individuals with cleft: a population-based register study. Cleft Palate Craniofac J 2012;49:153-9.

18 Wehby GL, Collet B, Barron S, et al. Academic achievement of children and adolescents with oral clefts. Pediatrics 2014;133:785-92.

19 Collett BR, Stott-Miller M, Kapp-Simon KA, et al. Reading in children with orofacial clefts versus controls. J Pediatr Psychol 2010;35:199-208.

20 Fitzsimons KJ, Mukarram S, Copley LP, et al. Centralisation of services for children with cleft lip or palate in England: a study of hospital episode statistics. BMC Health Serv Res 2012;12:148.

21 Ness AR, Wills AK, Waylen A, et al. Centralization of cleft care in the UK. Part 6: a tale of two studies. Orthod Craniofac Res 2015;18(Suppl 2):56-62. 


\section{Original article}

22 CRANE Project team on behalf of the Cleft Development Group. CRANE Database Annual Report. London: Clinical Effectiveness Unit, The Royal College of Surgeons of England, 2015.

23 The National Pupil Database. www.nationalpupildatabase.wikispaces.com (accessed 26 Aug 2017).

24 Health Research Authority. 2016. http://www.hra.nhs.uk/documents/2016/06/ defining-research.pdf (accessed 26 Aug 2017).

25 Department for Communities and local Government. The English Indices of Deprivation, 2015. https://www.gov.uk/government/uploads/system/uploads/ attachment_data/file/465791/English_Indices_of_Deprivation_2015_-_Statistical_ Release.pdf. (accessed 26 Aug 2017).

26 The NPD User Group. National Pupil Database: Free School Meals, 2011. http:// nationalpupildatabase.wikispaces.com/FSM. (accessed 26 Aug 2017).
27 Department for Education. National Statistics: Early years foundation stage profile, 2012. https://www.gov.uk/government/statistics/early-years-foundation-stage-profileresults-in-england-academic-year-2011-to-2012. (accessed 26 Aug 2017).

28 Department for Education. National Statistics: EYFS attainment by pupil characteristics, 2012. https://www.gov.uk/government/statistics/eyfsp-attainmentby-pupil-characteristics-in-england-academic-year-2011-to-2012. (accessed 26 Aug 2017).

29 Collett BR, Wehby GL, Barron S, et al. Academic achievement in children with oral clefts versus unaffected siblings. J Pediatr Psychol 2014;39:743-51.

30 Collett BR, Leroux B, Speltz ML. Language and early reading among children with orofacial clefts. Cleft Palate Craniofac J 2010;47:284-92.

31 Richman $L$. The effects of facial disfigurement on teachers' perception of ability in cleft palate children. Cleft Palate Journal 1978;15:155-60. 


\section{Correction: Early academic achievement in children with isolated clefts: a population-based study in England}

Fitzsimons KJ, Copley LP, Setakis E, et al. Early academic achievement in children with isolated clefts: a population-based study in England. Arch Dis Child 2018;103:356-62.

The authors have noticed that during the production process some errors were introduced into table 3. Many of the 95\% confidence interval ranges should be negative. We would like to apologise for these errors and the corrected table 3 is below. Also, in the abstract, a couple of numbers and one word need changing within the Results section. The following sentence should read: 'Academic achievement was significantly below national average for all six assessed areas with z-scores ranging from -0.24 (95\% CI -0.32 to 0.16 ) for knowledge of world to $-0.32(-0.42$ to -0.23$)$ for physical development.'

Table 3 Results of multivariable linear regression analyses of effect of cleft type on the z-scores for the six assessed areas of learning of the early years foundational stage profile (difference compared with $\mathrm{Cl}$ with $95 \% \mathrm{Cl}$ )

\begin{tabular}{|c|c|c|c|c|c|c|}
\hline Characteristic & $\begin{array}{l}\text { Personal, social } \\
\text { and emotional } \\
\text { development }\end{array}$ & $\begin{array}{l}\text { Communication, } \\
\text { language and } \\
\text { literacy }\end{array}$ & $\begin{array}{l}\text { Mathematical } \\
\text { development }\end{array}$ & $\begin{array}{l}\text { Knowledge and } \\
\text { understanding of } \\
\text { the world }\end{array}$ & $\begin{array}{l}\text { Physical } \\
\text { development }\end{array}$ & $\begin{array}{l}\text { Creative } \\
\text { development }\end{array}$ \\
\hline \multicolumn{7}{|l|}{ Cleft type } \\
\hline $\mathrm{CL}$ & Ref & Ref & Ref & Ref & Ref & Ref \\
\hline $\mathrm{CP}$ & $\begin{array}{l}-0.25 \\
(-0.35 \text { to }-0.15)\end{array}$ & $\begin{array}{l}-0.28 \\
(-0.38 \text { to }-0.19)\end{array}$ & $\begin{array}{l}-0.27 \\
(-0.37 \text { to }-0.17)\end{array}$ & $\begin{array}{l}-0.31 \\
(-0.41 \text { to }-0.20)\end{array}$ & $\begin{array}{l}-0.32 \\
(-0.44 \text { to }-0.20)\end{array}$ & $\begin{array}{l}-0.28 \\
(-0.39 \text { to }-0.18)\end{array}$ \\
\hline UCLP & $\begin{array}{l}-0.11 \\
(-0.22 \text { to }-0.01)\end{array}$ & $\begin{array}{l}-0.19 \\
(-0.28 \text { to }-0.09)\end{array}$ & $\begin{array}{l}-0.15 \\
(-0.26 \text { to }-0.05)\end{array}$ & $\begin{array}{l}-0.18 \\
(-0.29 \text { to }-0.07)\end{array}$ & $\begin{array}{l}-0.14 \\
(-0.26 \text { to }-0.01)\end{array}$ & $\begin{array}{l}-0.15 \\
(-0.26 \text { to }-0.03)\end{array}$ \\
\hline BCLP & $\begin{array}{l}-0.19 \\
(-0.33 \text { to }-0.05)\end{array}$ & $\begin{array}{l}-0.30 \\
(-0.43 \text { to }-0.17)\end{array}$ & $\begin{array}{l}-0.19 \\
(-0.33 \text { to }-0.04)\end{array}$ & $\begin{array}{l}-0.25 \\
(-0.40 \text { to }-0.10)\end{array}$ & $\begin{array}{l}-0.37 \\
(-0.54 \text { to }-0.21)\end{array}$ & $\begin{array}{l}-0.25 \\
(-0.40 \text { to }-0.10)\end{array}$ \\
\hline \multicolumn{7}{|l|}{ IDACI } \\
\hline (most deprived) 1 & Ref & Ref & Ref & Ref & Ref & Ref \\
\hline 2 & $\begin{array}{l}0.09 \\
(-0.02 \text { to } 0.21)\end{array}$ & $\begin{array}{l}0.11 \\
(0.00 \text { to } 0.22)\end{array}$ & $\begin{array}{l}0.18 \\
(0.07 \text { to } 0.30)\end{array}$ & $\begin{array}{l}0.23 \\
(0.11 \text { to } 0.35)\end{array}$ & $\begin{array}{l}0.13 \\
(-0.01 \text { to } 0.27)\end{array}$ & $\begin{array}{l}0.16 \\
(0.03 \text { to } 0.28)\end{array}$ \\
\hline 3 & $\begin{array}{l}0.25 \\
(0.13 \text { to } 0.37)\end{array}$ & $\begin{array}{l}0.32 \\
(0.21 \text { to } 0.44)\end{array}$ & $\begin{array}{l}0.40 \\
(0.28 \text { to } 0.53)\end{array}$ & $\begin{array}{l}0.45 \\
(0.32 \text { to } 0.58)\end{array}$ & $\begin{array}{l}0.30 \\
(0.15 \text { to } 0.44)\end{array}$ & $\begin{array}{l}0.37 \\
(0.24 \text { to } 0.50)\end{array}$ \\
\hline 4 & $\begin{array}{l}0.41 \\
(0.29 \text { to } 0.54)\end{array}$ & $\begin{array}{l}0.48 \\
(0.36 \text { to } 0.59)\end{array}$ & $\begin{array}{l}0.55 \\
(0.42 \text { to } 0.68)\end{array}$ & $\begin{array}{l}0.54 \\
(0.40 \text { to } 0.67)\end{array}$ & $\begin{array}{l}0.43 \\
(0.28 \text { to } 0.58)\end{array}$ & $\begin{array}{l}0.50 \\
(0.36 \text { to } 0.63)\end{array}$ \\
\hline (least deprived) 5 & $\begin{array}{l}0.51 \\
(0.37 \text { to } 0.64)\end{array}$ & $\begin{array}{l}0.58 \\
(0.46 \text { to } 0.71)\end{array}$ & $\begin{array}{l}0.71 \\
(0.57 \text { to } 0.84)\end{array}$ & $\begin{array}{l}0.69 \\
(0.55 \text { to } 0.83)\end{array}$ & $\begin{array}{l}0.53 \\
(0.37 \text { to } 0.69)\end{array}$ & $\begin{array}{l}0.59 \\
(0.45 \text { to } 0.74)\end{array}$ \\
\hline \multicolumn{7}{|l|}{ Free school meals } \\
\hline No & Ref & Ref & Ref & Ref & Ref & Ref \\
\hline Yes & $\begin{array}{l}-0.38 \\
(-0.48 \text { to }-0.27)\end{array}$ & $\begin{array}{l}-0.47 \\
(-0.57 \text { to }-0.38)\end{array}$ & $\begin{array}{l}-0.41 \\
(-0.52 \text { to }-0.31)\end{array}$ & $\begin{array}{l}-0.36 \\
(-0.47 \text { to }-0.25)\end{array}$ & $\begin{array}{l}-0.34 \\
(-0.46 \text { to }-0.21)\end{array}$ & $\begin{array}{l}-0.35 \\
(-0.46 \text { to }-0.24)\end{array}$ \\
\hline \multicolumn{7}{|l|}{ Ethnicity } \\
\hline White & Ref & Ref & Ref & Ref & Ref & Ref \\
\hline Other & $\begin{array}{l}-0.07 \\
(-0.17 \text { to } 0.03)\end{array}$ & $\begin{array}{l}-0.08 \\
(-0.18 \text { to } 0.01)\end{array}$ & $\begin{array}{l}-0.14 \\
(-0.24 \text { to }-0.03)\end{array}$ & $\begin{array}{l}-0.14 \\
(-0.25 \text { to }-0.03)\end{array}$ & $\begin{array}{l}-0.05 \\
(-0.17 \text { to } 0.07)\end{array}$ & $\begin{array}{l}-0.08 \\
(-0.19 \text { to } 0.03)\end{array}$ \\
\hline \multicolumn{7}{|l|}{ Sex } \\
\hline Girls & Ref & Ref & Ref & Ref & Ref & Ref \\
\hline Boys & $\begin{array}{l}-0.36 \\
(-0.44 \text { to }-0.28)\end{array}$ & $\begin{array}{l}-0.33 \\
(-0.41 \text { to }-0.26)\end{array}$ & $\begin{array}{l}-0.18 \\
(-0.26 \text { to }-0.10)\end{array}$ & $\begin{array}{l}-0.15 \\
(-0.24 \text { to }-0.07)\end{array}$ & $\begin{array}{l}-0.42 \\
(-0.52 \text { to }-0.32)\end{array}$ & $\begin{array}{l}-0.58 \\
(-0.66 \text { to }-0.49)\end{array}$ \\
\hline R-Squared $¥$ & 0.097 & 0.14 & 0.118 & 0.1 & 0.079 & 0.123 \\
\hline
\end{tabular}

Open access This is an open access article distributed in accordance with the Creative Commons Attribution Non Commercial (CC BY-NC 4.0) license, which permits others to distribute, remix, adapt, build upon this work noncommercially, and license their derivative works on different terms, provided the original work is properly cited, appropriate 
credit is given, any changes made indicated, and the use is non-commercial. See: http://creativecommons.org/licenses/by-ncl 4.0\%.

(C) Author(s) (or their employer(s)) 2021. Re-use permitted under CC BY-NC. No commercial re-use. See rights and permissions. Published by BMJ.

Arch Dis Child 2021;106:e38. doi:10.1136/archdischild-2017-313777corr1

(D) Check for updates 